\title{
Korte historiek van het aandeel van de diergeneeskunde in het experimenteel onderzoek in de humane geneeskunde
}

\author{
A short description of veterinary contributions to experimental research \\ in human medicine
}

\author{
${ }^{1} \mathbf{J}$. Bouckaert, ${ }^{2}$ L. Devriese
}

${ }^{1}$ Museum voor de Geschiedenis van de Geneeskunde

Onderbergen 1, B-9000 Gent, Belgium

${ }^{2}$ UGent Collectie Diergeneeskundig Verleden, Salisburylaan 133, B-9820 Merelbeke, Belgium

\section{AMENVATTING}

Een korte beschrijving wordt gegeven van het leven en werk van dierenartsen die een rol hebben gespeeld in de ontwikkeling van de humane geneeskunde. Toeval of niet, alle hier aangehaalde figuren droegen in de eerste plaats bij tot de kennis van infectieuze ziekten. Als microbiologen kunnen hier vernoemd worden: Edmond Nocard, wiens naam werd gegeven aan het door hem beschreven bacteriegeslacht Nocardia en de gelijknamige ziekte, Victor Babès en Arnold Theiler die zich verdienstelijk hebben gemaakt in de parasitologie. Daarvan getuigen de geslachten Babesia en Theileria. De welbekende Salmonella en salmonellose ontlenen hun naam aan de Amerikaanse dierenarts Daniël Salmon. Karl F. Meyer gaf de eerste beschrijving van wat nu Mycoplasma is en leverde baanbrekend werk in de studie naar miltvuur en een reeks andere ziekte-agentia. Niet minder belangrijk was zijn aandeel in de introductie van de begrippen kiemreservoir en latente infectie.

Naast de ontdekkingen in verband met infectieuze ziekten is er het aandeel van dierenartsen in de kennis van immuniteit. Auguste Chauveau vormde met zijn 'retentietheorie' de basis van de kennis van weerstand tegen bacteriën en virussen. De ontwikkeling door Gaston Ramon van anatoxines, geneutraliseerde toxines die immuniteit geven tegen onder meer tetanos en difterie, vormde een mijlpaal in de dagelijks toegepaste geneeskunde. Als chronologisch laatste in de rij moet Peter Doherty vermeld worden. Hij is de enige dierenarts die de Nobelprijs geneeskunde kreeg; dit voor zijn aandeel in de ontdekkingen omtrent cellulaire immuniteit.

\section{ABSTRACT}

A short description is given of the life and work of scientists active in veterinary research, who contributed substantially to the knowledge of human disease and health. Microbiology and immunology were their main fields of interest. Important microbiologists include Edmond Nocard, Karl F. Meyer, Daniel Salmon, Victor Babès and Arnold Theiler. Still others were mainly active as immunologists. Gaston Ramon's works on bacterial toxins resulted in effective vaccines against tetanos as well as diphteritis, until then an important cause of child mortality. Early findings of Auguste Chauveau established a basis for understanding immunity to microbial diseases. Nobel prize-winning Peter C. Doherty helped to elucidate the complex mechanisms of cellular immunity.

\section{INLEIDING}

Tot aan Vesalius' tijd (16 $6^{\text {de }}$ eeuw) werden anatomische bevindingen van onderzoek bij dieren gewoon op de mens overgebracht. Lijkschouwingen bij mensen waren immers door wereldlijke en kerkelijke overheden verboden. De Egyptenaren hadden een beperkte kennis van het menselijk lichaam dank zij het balsemen van lijken. In de Grieks-Alexandrijnse School had men een zeker inzicht verworven door invivodissectie bij gevangenen en ter dood veroordeelden. Deze bevindingen zijn echter grotendeels verlo- 


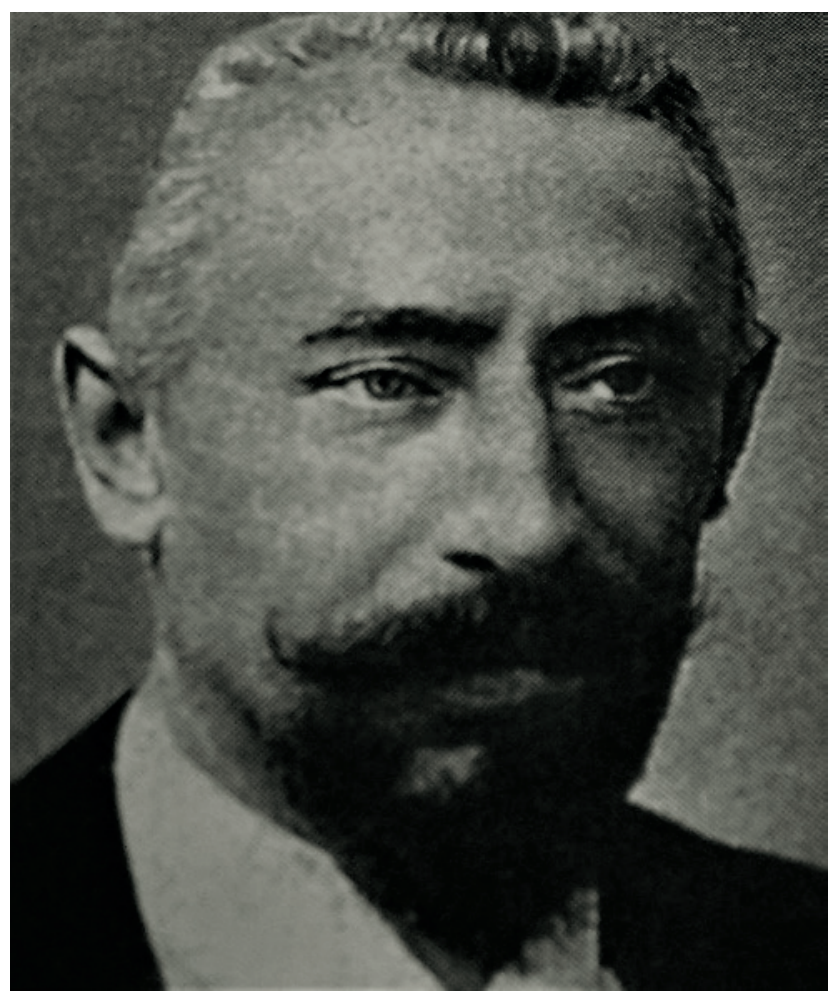

Figuur 1. Edmond Nocard

ren gegaan na de brand van de befaamde bibliotheek in het jaar 389. De School heeft wel een grote invloed gehad op de ontwikkeling van de Grieks-Latijnse geneeskunde. Zo bleef de anatomie van de mens echter gedurende lange tijd uitsluitend gebaseerd op de beschrijving door Galenus, die vermoedelijk enkel dieren had ontleed. De stichting van scholen op universitair niveau voor de opleiding van dierenartsen eind $18 \mathrm{de}$ - begin 19de eeuw betekende een grote vooruitgang in de studie van de opbouw en de werking van verschillende organen en orgaanstelsels. Datzelfde geldt voor de ontdekking van de rol van meerdere micro-organismen in ziekten bij de mens, evenals de studie van het ontstaan van immuniteit en het beschermen tegen infectie door vaccinatie.

De verdiensten van enkele belangrijke dierenartsen die hieraan meewerkten, worden hieronder min of meer chronologisch bondig beschreven. Misschien niet toevallig waren de meesten van hen werkzaam op het terrein van de immunologie en de microbiologie, vooral in verband met bacteriën en parasieten die zowel dieren als mensen infecteren.

\section{PERSOONLIJKHEDEN}

Edmond Isidore Nocard, geboren in 1850, studeerde in Alfort (Chauveau et al., 1906) (Figuur 1). Hij werd er instructeur en later directeur. Zijn interesse voor besmettelijke ziekten bij dieren leidde tot samenwerking met Louis Pasteur. Op die manier kon hij meerdere oorzakelijke kiemen identificeren, zoals Chlamidia psittaci die verantwoordelijk is voor psittacose of papegaaienziekte, of meer algemeen orni- those genoemd (letterlijk: vogelziekte).

(Jean Baptiste) Auguste Chauveau, geboren in 1850, studeerde eerst in Alfort, later behaalde hij zijn graduaat in Lyon (Magne, 1917) (Figuur 2). Hij was een veelzijdig man als dierenarts, anatoom, fysioloog en microbioloog. In 1875 werd hij directeur van de veterinaire school aldaar en nadien inspecteurgeneraal van de Franse veterinaire instituten. Hij bekleedde de leerstoel van toegepaste anatomie in Lyon en werd directeur van het Natuurhistorisch Museum aldaar. Dit resulteerde in zijn werk 'Traité d' anatomie comparée des animaux domestiques', een basiswerk dat herhaaldelijk heruitgegeven en vertaald werd. Het bevat prachtige anatomische afbeeldingen van dieren, meestal paarden. Zijn 'retentietheorie' hield in dat kiemen in het lichaam stoffen achterlaten en zo een zekere immuniteit teweegbrengen. Aldus werd hij samen met zijn medewerker Toussaint de theoretische voorloper van de vaccinatiepraktijk, nog vóór Pasteur. In de geschiedenis van de geneeskunde werd dit echter ten onrechte vergeten. Zijn fysiologische studies over de relatie van warmte en energie met de spierwerking en zijn retentietheorie waren baanbrekend.

Daniël Elmer Salmon (1850-1914) was een van de eerste gediplomeerde dierenartsen in de Verenigde Staten (Dunlop en Williams, 1996; Roncalli, 1998) (Figuur 3). Na zijn studies aan de Cornell University verbleef hij eveneens een tijdje in Alfort bij Parijs. Terug in de VSA vestigde hij zich eerst als dierenarts,

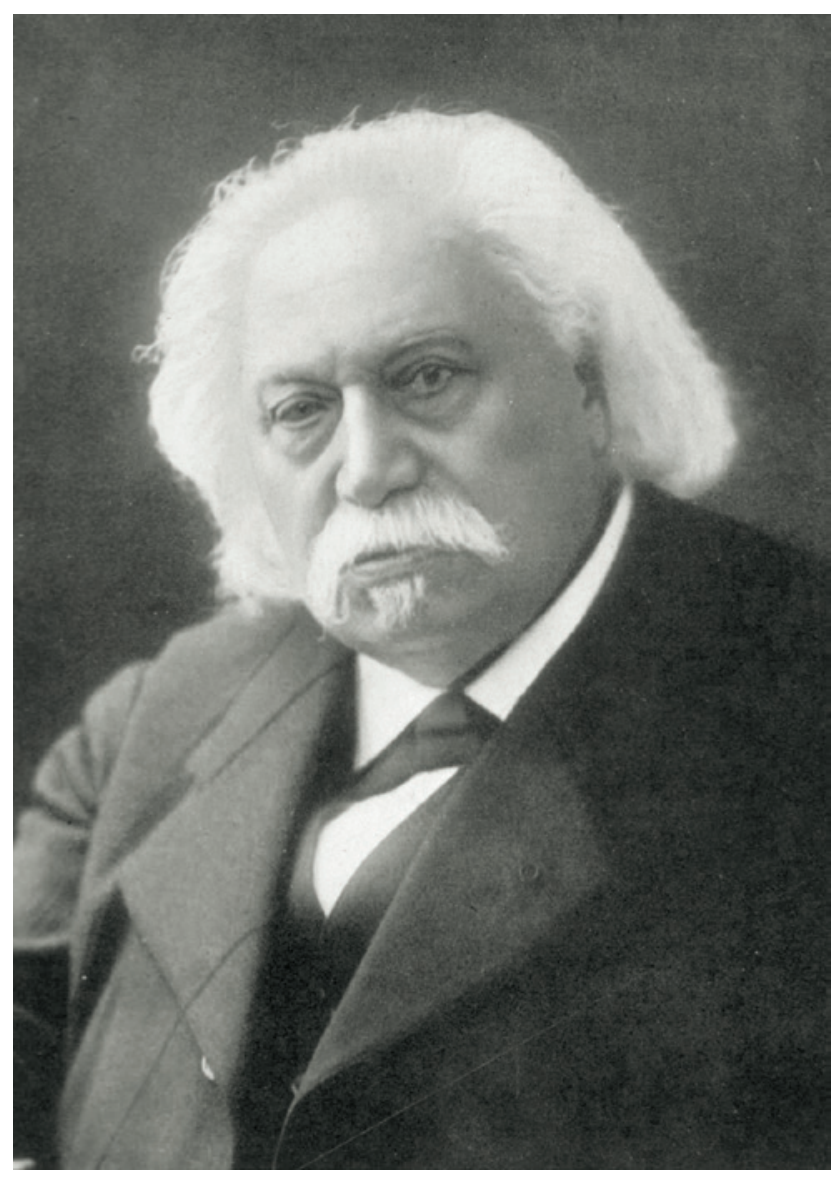

Figuur 2. Auguste Chauveau 


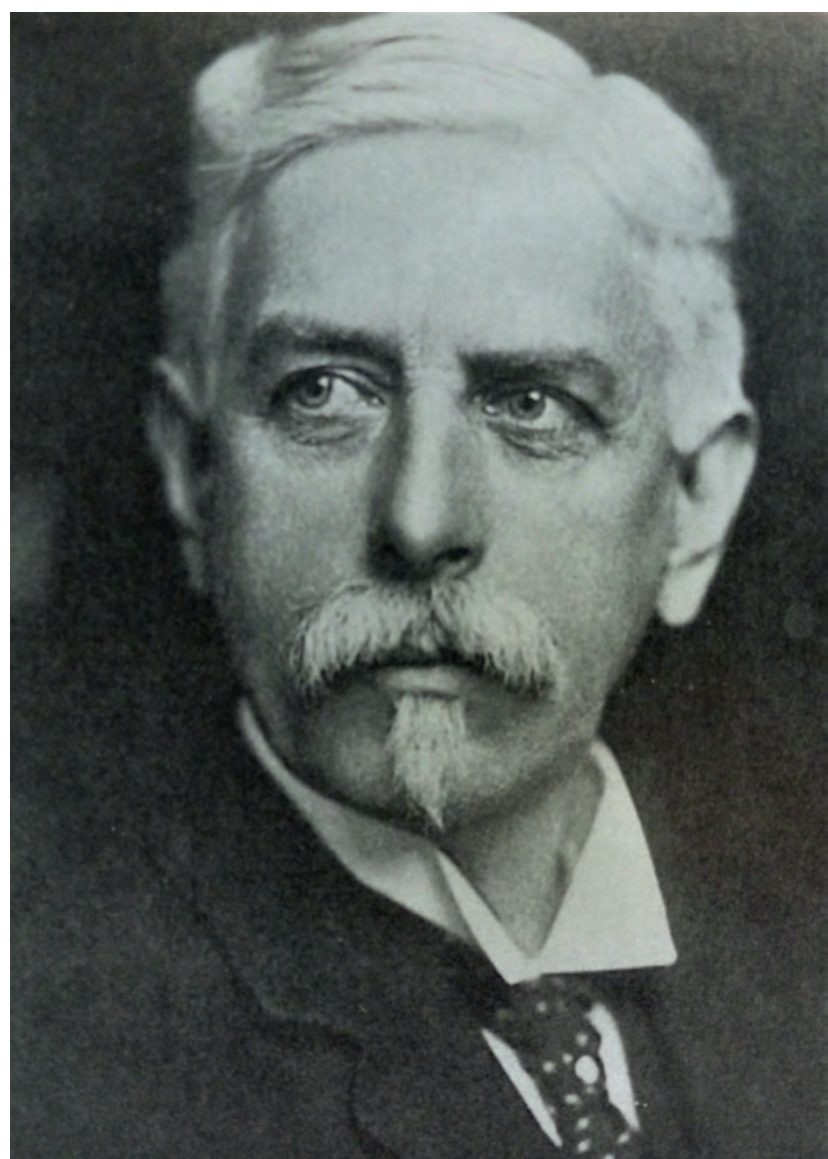

Figuur 3. Daniël Salmon

maar richtte voor het Ministerie van Landbouw het Departement Veeziekten in, waar hij gans zijn leven aan wijdde. Onder zijn impuls kon de zeer besmettelijke boviene pleuropneumonie worden uitgeroeid. Vleesinspectie en controle van in- en uitgevoerde dieren werden eveneens door hem ingevoerd. In 1885 ontdekte een assistent een nieuw genus micro-organismen, waaraan ter zijner ere de naam Salmonella werd gegeven. Sindsdien zijn er een tweeduizendtal serotypes van bekend. Van 1906 tot 1911 verbleef hij aan de Universiteit van Montevideo om er het Veterinaire Departement op te richten.

Victor Babès (1854-1926) was een Roemeense arts die zijn belangrijkste werk verrichte na zijn benoeming in 1886 tot professor in de pathologie en bacteriologie aan de diergeneeskundige faculteit van Boekarest (Curca, 2004) (Figuur 4). Dit liet hem toe het onderzoek te leiden naar de oorzaak van hemoglobinurie, een belangrijke ziekte bij runderen in de Donauvlakte. Dit resulteerde in de beschrijving van een endoglobulaire protozoa die Babès de naam Haematococcus bovis gaf. Dit werd later naar hem Babesia bovis genoemd. De ziekte zelf kreeg namen mee als "Texas cattle fever", "redwater", piroplasmose en tenslotte ook babesiose. Bij schapen en geiten ontdekte Babès een verwant micro-organisme dat eveneens naar de ontdekker genoemd werd: Babesiella (nu Babesia) ovis. Transmissie gebeurt door teken. Deze agentia zijn verwant met de verwekker van malaria. Ze werden samen als Trypanosoma ondergebracht in het phyllum Apicomplexa.

Dierenarts Gaston Ramon (1886-1963) was vooral bedrijvig in het Pasteur Instituut, waar zijn inbreng belangrijk was voor de ontwikkeling van het difterievaccin (Figuur 5). Hij bestudeerde eerst bij paarden het ontstaan van de immuniteit door de vorming van anatoxines: onschadelijk gemaakte immuniserende toxines, die bij mens en dier zouden toegepast worden. Zijn belangrijkste vondst betrof het neutraliseren van toxines met formol, zodat ze geen ziekte meer veroorzaakten, maar wel immuniteit opwekten. Een tweede initiatief van hem leidde tot het combineren van anatoxines, zoals die van difterie en tetanos. Samen met het kinkhoestvaccin (kinkhoest verwekt door Bordetella pertussis) werd deze entstofcombinatie bekend als 'DiTePer', lange tijd bij kinderen toegepast. Tot op het moment dat het vaccin van Ramon beschikbaar werd, was difterie (kroep) een van de belangrijkste oorzaken van kindersterfte. Als opvolger van Albert Calmette -die samen met Guérin het BCG-vaccin ontwikkeld had- was deze dierenarts jarenlang directeur van het Parijse Pasteur Instituut. Na de oorlog nam hij onder druk ontslag uit de directie van Pasteur, omdat hij contacten had gehad met Duitse wetenschappers. Toch kreeg hij later erkenning als directeur van het Franse Institut National d' Hygiène en van het Office international des Epizooties (vee-epidemieën) te $\mathrm{Pa}-$ rijs. Hij werd meerdere malen genomineerd voor de Nobelprijs, maar kreeg hem nooit (Butler 2016).

Arnold Theiler (1867-1936) was een Zwitser die

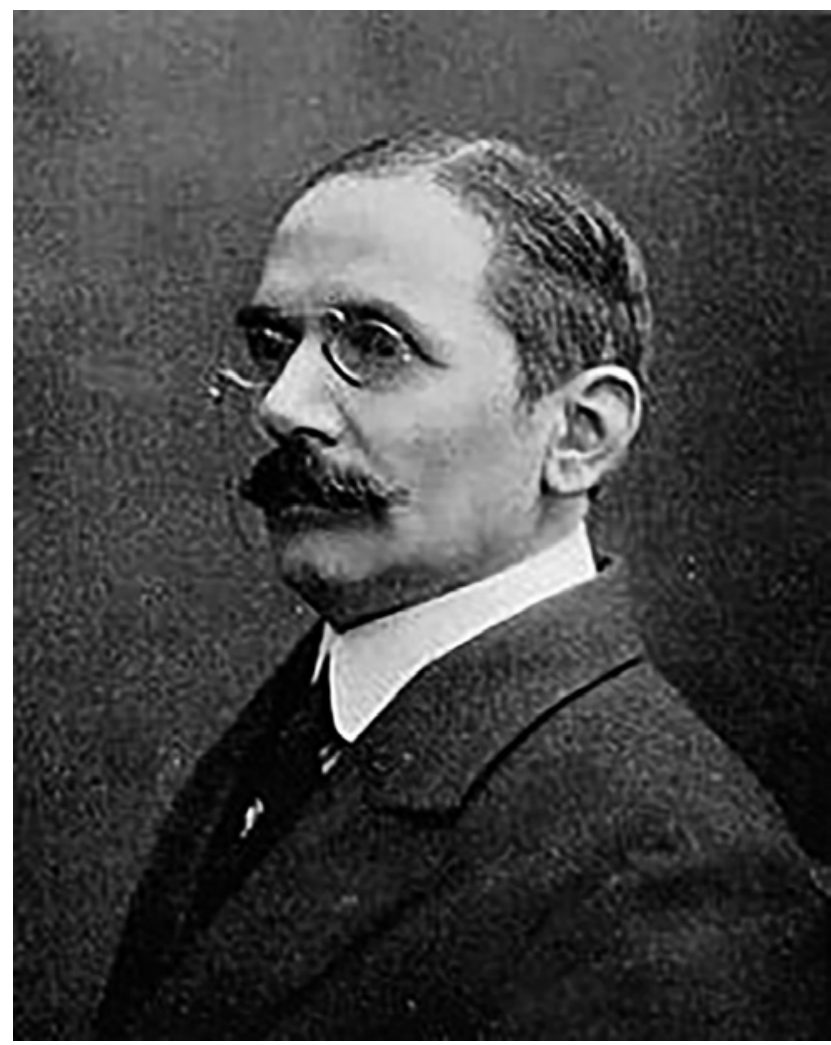

Figuur 4. Victor Babès 


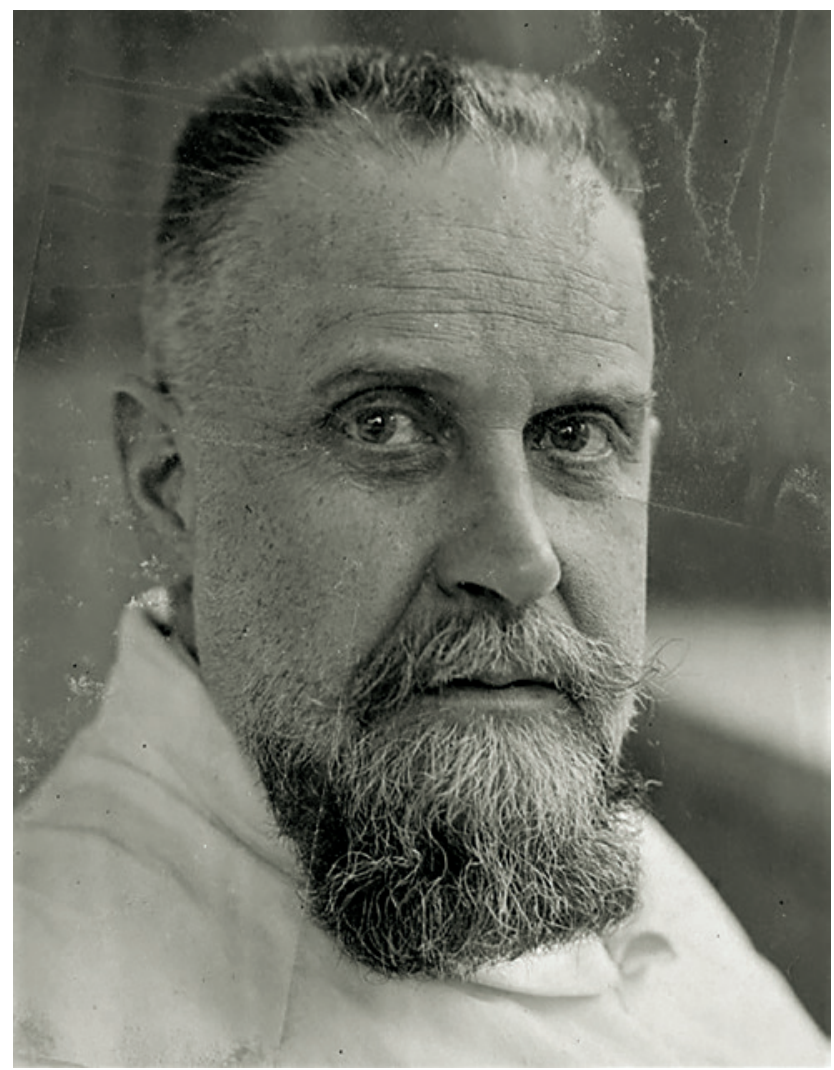

Figuur 5. Gaston Ramon

in Zürich het dierenartsendiploma haalde, maar die vooral in Onderstepoort (Zuid-Afrika) werkzaam was (Bigalke, 2004) (Figuur 6). Bij zijn talrijke en gevarieerde onderzoeken naar oorzaken en behandeling van infectieuze veeziekten, was hij vooral geïnteresseerd in de rol van protozoa. In 1910 beschreef hij Anaplasma marginale en toonde hij aan dat "East Coast fever" bij runderen overgebracht werd door teken. De verwekker werd Theileria parva genoemd en de ziekte theileriose. Paardenpiroplasmose wordt eveneens overgebracht door teken en kan veroorzaakt worden zowel door Theileria equi als door Babesia cabali (cf. Victor Babès). Bij artsen is het amper geweten dat theileriose ook in onze streken ooit een gevreesde aandoening bij mensen was: polderkoorts. De ziekte verloor haar bedreigend karakter door ingrijpende droogleggingswerken, met name door het graven van de Leopoldvaart, alias de 'Blinker', in het noorden van Oost- en West-Vlaanderen. Dit gebeurde al in 1843-1854, nog vóór de eigen aard van de infectie bekend was: men had het over malaria. Het onderscheid is niet onbelangrijk: ook bij mensen wordt Theileria door teken overgedragen, dit in tegenstelling tot malaria die -zoals welbekend- muggen behorend tot het geslacht Anopheles als vector heeft.

Karl Friedrich Meyer (1884-1974) was net als Theiler een Zwitserse dierenarts die in Zuid-Afrika aan een uiterst vruchtbare onderzoekscarrière begon (Steele, 1974; Sabin, 1980; Honigsbaum, 2016) (Figuur 7). Daar ontdekte en beschreef hij bij runderen lijdend aan pleuropneumonie, een tot dan toe onbe- kend type bacteriën die hij P.P.L.O. ("pleuro-pneumonia-like organisms") noemde. Later werden ze bekend als mycoplasmen. Al spoedig verhuisde Meyer naar de VSA, waar hij baanbrekende ontdekkingen deed bij ziekten verwekt door sterk verschillende micro-organismen: brucellose, botulisme, paardenencefalitis, "yellow fever", pest, psittacose, leptospirose, coccidiö̈domycose ("California Valley fever") en vergiftiging door arthroconidia geassocieerd met mossels. K.F, zoals hij gemeenzaam bekend stond, had een belangrijk aandeel in de introductie en aanvaarding van de begrippen 'latente infectie' en 'kiemreservoir' in het dierenrijk. Niet helemaal onterecht werd deze duizendpoot wel eens de Pasteur van de twintigste eeuw genoemd.

Peter C. Doherty (1940- ) was de eerste en tot op heden enige dierenarts die de Nobelprijs voor Geneeskunde ontving, samen met Rolf Zinkernagel in 1995 (Figuur 8). Hij werd geboren in Brisbane uit een familie met Ierse roots en studeerde diergeneeskunde aan de Universiteit van Queensland. Zijn eerste post na zijn studies was Veterinary Officer aan het Departement Landbouw en Veeteelt. Alhoewel hij vroeg om labowerk te kunnen verrichten, werd hij de landelijke praktijk ingestuurd en moest hij honderden kilometers afleggen. Zijn taak bestond onder andere in het opsporen van infectieziekten en vooral van doodsoorzaken bij overleden dieren. Nadat hij trichomonose vaststelde in een gebied dat door de autoriteiten daarvan uitgeroeid verklaard was, werd hij prompt ver-

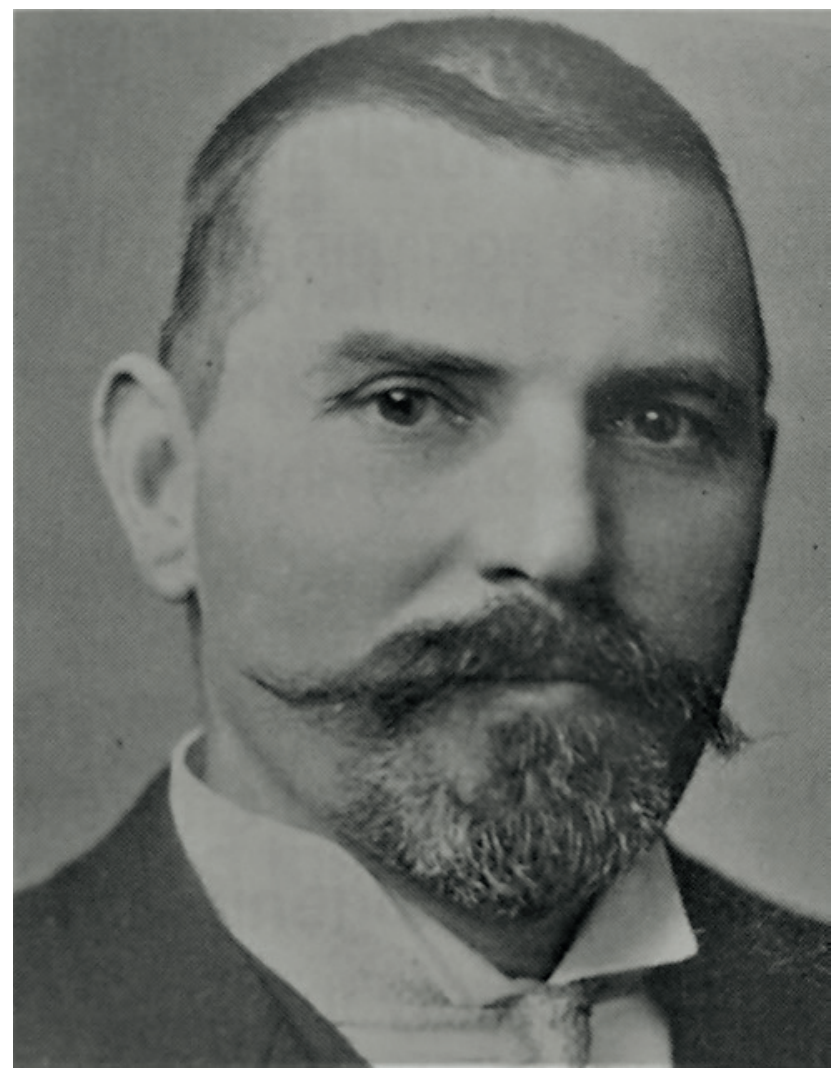

Figuur 6. Arnold Theiler 


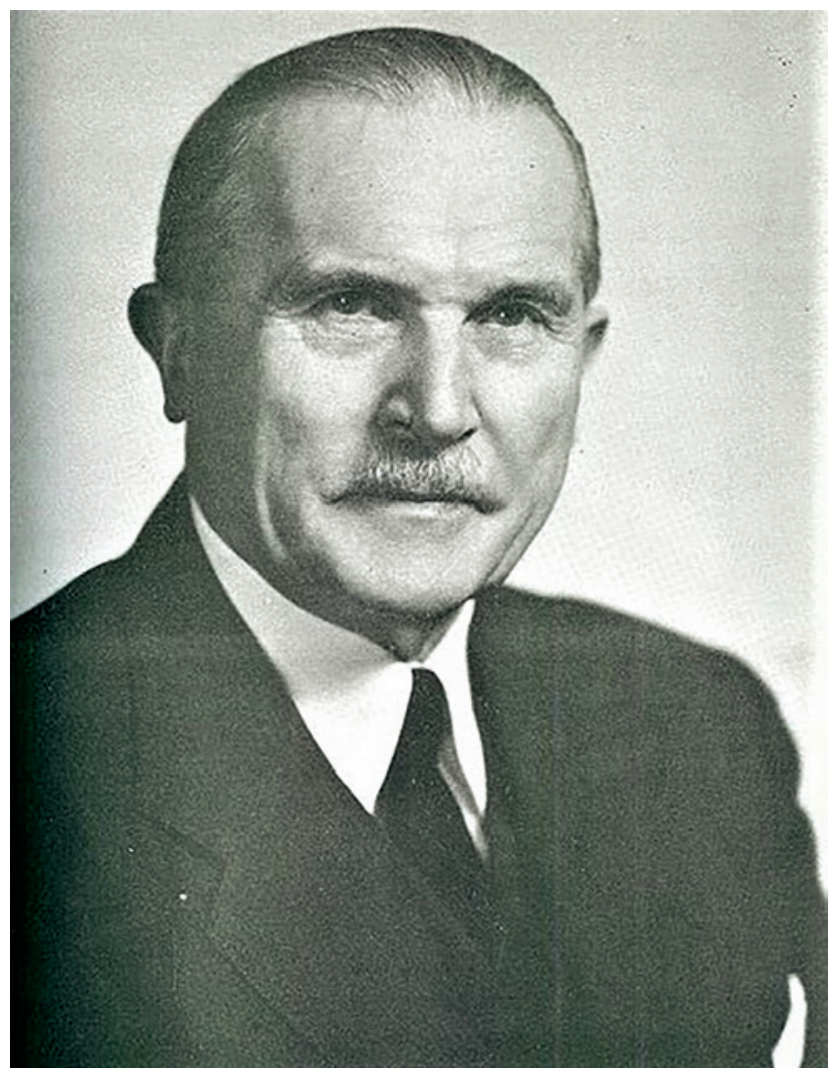

Figuur 7. Karl F. Meyer

plaatst naar het regionale Animal Research Institute. Daar kon hij wetenschappelijk onderzoek verrichten en zich specialiseren in de virologie, waarna hij een post aangeboden kreeg in Edinburgh (Schotland) om verder te werken. Hierbij stelde hij vast dat weinig bekend was over de immunologie bij virale infecties. Samen met de uitgeweken Zwitser Zinkernagel vormde hij vanaf 1973 een hecht team. Zo ontdekten ze de werkwijze van het cellulaire immuunstelsel om vreemde micro-organismen en eigen cellen van elkaar te onderscheiden. Dit bleek zeer nuttig bij het onderzoek naar bepaalde vormen van kanker en van auto-immuunziekten. Ook voor het vermijden van afstoting bij transplantaties bleek dit van belang. In de literatuurlijst hieronder is een link te vinden naar een korte, maar pittige autobiografie van Doherty zelf (2019).

\section{DISCUSSIE}

Vermelden we tot slot nog het werk van anderen die niet echt een bijdrage leverden tot de kennis van humane aandoeningen, maar die in hun gebied ongewoon verdienstelijk waren: Henri Marie Bouley (1814- 1885) werd, dank zij zijn hechte samenwerking met Louis Pasteur, verkozen tot lid en later president van de Franse Academie voor Geneeskunde. Alex François Liautard (1835-1918) werd secretaris en later voorzitter van de door hem opgerichte US Ve- terinary Medical Association. Hij wordt de vader van de diergeneeskunde in de VS genoemd. Ludwig Franz Heck (1860-1951) doctoreerde in de zoölogische systematiek, werd zoo-directeur en schreef uitgebreid over de medische zorg van dieren, werk waarvoor hij een honoraire graad van doctor in de Diergeneeskunde kreeg.

Het zou niemand mogen verwonderen dat alle hier besproken figuren mannen zijn. Vrouwen waren zelfs nog niet actief in het beroep, laat staan dat ze de mogelijkheid zouden gekregen hebben aan wetenschappelijk onderzoek te doen. Moeilijker te verklaren is het gegeven dat de bekend gebleven pioniers allen meestal in teamverband minstens gedeeltelijk werkzaam waren als microbiologen, of als pathologen en immunologen onderzoek deden naar infectieuze ziekten.

Tussen veterinaire en menselijke geneeskunde was en is nog steeds veel samenwerking. Experimenten op dieren waren en blijven nodig in het medisch onderzoek. Het Softenon-drama duwde ons een halve eeuw geleden met de neus op de feiten. Corneel Heymans zou trouwens nooit de Nobelprijs verworven hebben zonder zijn studies op honden. Het onderzoek gebeurde en gebeurt nog steeds met eencellige dieren, celculuren, insecten, zoals fruitvliegjes, verder muizen en ratten, konijnen, cavia's, honden, varkens en

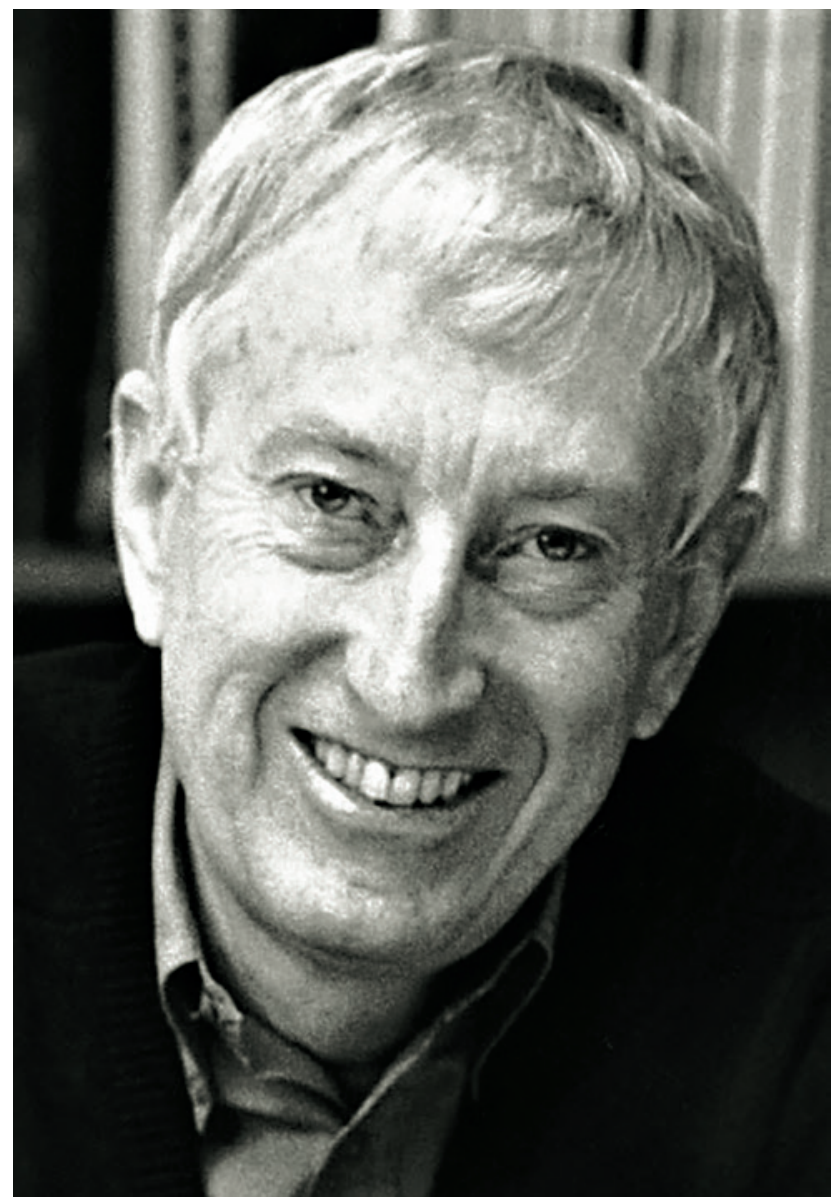

Figuur 8. Peter C. Doherty 
mensapen. Vooral tegen proeven met deze laatsten zijn ernstige ethische bezwaren in te brengen. Dierlijke experimenten zullen nooit volledig kunnen vervangen worden door in-vitro- of proefbuisonderzoek of door computersimulatie. De voorgenomen proeven moeten goedgekeurd worden door ethische commissies en uiteraard is vivisectie niet meer toegelaten. Strenge regels voor het welzijn van die dieren moeten nageleefd worden.

De afbeeldingen werden overgenomen uit het tijdschrift Historia Medicinae Veterinariae, uit de publicaties van Lombard et al. (2007), van Mathijsen (1997) en Dunlop en Williams (1996) en uit wikimediacommons.

\section{REFERENTIES}

Bigalke, R.D. (2004). Theiler, Arnold. Historia Medicinae Veterinariae 29, 95-98.

Blancou, J. 1960). Nocard, vétérinaire et pastorien de la première heure. Cahiers de Médecine vétérinaire 29 (3), 65-93.

Butler, D. (2016). Close but no Nobel: the scientists who never won. Nature - News, 11 October.

Chauveau, A., Leclainche, E., Roux, (1906). Edmond Nocard. Masson, Parijs, 1-85.

Curca, D. (2004). Babès, Victor. Historia Medicinae Veterinariae $29,95-98$.
Doherty, P. C. (2019). NobelPrize.org. Nobel Media AB 2019. Wed. 18 Sep 2019. https://www.nobelprize.org/ prizes/medicine/1996/doherty/biographical/

Dunlop, R.R., Williams, D.J. (1996). Veterinary Medicine, an Illustrated History. Mosby, Elsevier, Maryland Heights, MO, 556, 579-580.

Honigsbaum, M. (2016). Tipping the balance: Karl Friedrich Meyer. Latent infections, and the birth of modern ideas in disease ecology. Journal of the History of Bio$\log y$ 49, 261-309.

Lombard, M.F., Pastoret, P.P., Moulin, A.M. (2007). A brief history of vaccines and vaccination. Revue Scientifique et Technique de l'Office International des Epizooties, 26 (1), 29-48.

Magne, H. (1917). L'oeuvre scientifique de Chauveau. Recueil de Médecine Vétérinaire 93 (5) 111-121.

Mathijsen, A. (1997). The origins of veterinary schools in Europe - a comparative view. Nederlands Historisch Genootschap, Utrecht.

Roncalli, R.A. (1998). Salmon - parasitology and beyond. Journal of the American Veterinary Medical Association 212,1859 .

Sabin, A.D. (1980). Karl Friedrich Meyer, May 19, 1984-April 27, 1974. Biographical Memoirs 42, 268 332. National Academy of Sciences of the United States of America, Washington DC, National Academy Press.

Steele, J.H. (1974). Karl Friedrich Meyer. Journal of Infectious Diseases. Supplement 129, 404-411. 